\begin{tabular}{|l|l|l||}
\hline \multicolumn{2}{|c|}{ PublisherInfo } \\
\hline \hline PublisherName & $:$ & BioMed Central \\
\hline \hline PublisherLocation & $:$ & London \\
\hline \hline PublisherImprintName & $:$ & BioMed Central \\
\hline \hline
\end{tabular}

\title{
Very old bugs
}

\begin{tabular}{|l|l|l||}
\hline \multicolumn{2}{|c|}{ ArticleInfo } \\
\hline \hline ArticleID & $:$ & 3805 \\
\hline \hline ArticleDOI & $:$ & $10.1186 /$ gb-spotlight-20001019-02 \\
\hline \hline ArticleCitationID & $:$ & spotlight-20001019-02 \\
\hline \hline ArticleSequenceNumber & $:$ & 242 \\
\hline \hline ArticleCategory & $:$ & Research news \\
\hline \hline ArticleFirstPage & $:$ & 1 \\
\hline \hline ArticleLastPage & $:$ & 2 \\
\hline \hline & & RegistrationDate : 2000-10-19 \\
ArticleHistory & $:$ & OnlineDate \\
\hline \hline ArticleCopyright & $:$ & BioMed Central Ltd2000-10-19 \\
\hline \hline ArticleGrants & $:$ & \\
\hline \hline ArticleContext & $:$ & 130591111 \\
\hline \hline
\end{tabular}




\section{William Wells}

Email: wells@biotext.com

In the 19 October Nature Vreeland et al. report that the longevity record for bacteria has been smashed (Nature 2000, 407:897-900). The previous record holder was a Bacillus identified from the abdominal contents of a bee preserved in amber some 25 to 40 million years ago. The newly identified bacterium is also a Bacillus, but comes from a brine inclusion within a 250 million-year-old salt crystal. The crystal was found $569 \mathrm{~m}$ below the surface, in the wall of an air-intake shaft of a waste isolation pilot plant in Carlsbad, New Mexico. Surface sterilization of the crystal with acid and alkali reduced the probability of contamination to less than 1 in 109.

\section{References}

1. Nature, [http://www.nature.com/nature/]

2. Revival and identification of bacterial spores in 25- to 40-million-year-old Dominican amber. 